\title{
ABSTRAK \\ PERANAN KUALITAS PRODUK, SUKU BUNGA DAN ATRIBUT PROPERTY PENGARUHNHYA TERHADAP KEPUASAN NASABAH KPR DI PT BANK MAYBANK INDONESIA TBK CABANG TANGERANG
}

\author{
Oleh : Imas Sukaesih
}

\author{
Dosen Universitas Islam Syekh-Yusuf Tangerang \\ Program Studi Manajemen
}

Kebutuhan papan (rumah) merupakan kebutuhan dasar manusia yang berupa untuk hidup dan bersosialisasi. Rumah dapat berfungsi sebagai tempat untuk menikmati kehidupan yang nyaman, tempat untuk beristirahat, tempat berkumpulnya keluarga, dan tempat untuk menunjukkan tingkat sosial dalam masyarakat. Dalam konteks pemberian KPR, saat ini terdapat banyak lembaga keuangan yang menyediakan jasa kepemilikan rumah. Salah satunya adalah Maybank Indonesia. Maybank Indonesia memberikan solusi bagi pihak yang membutuhkan hunian dengan cepat dan mudah. Kredit Kepemilikan Properti (KPP) mencakup semua fasilitas kepemilikan properti yang terangkum di dalamnya.

Penelitian ini bertujuan untuk mengetahui seberapa besar pengaruh Kualitas Produk, Suku Bunga dan Atribut Property secara bersama-sama terhadap Kepuasan Nasabah KPR di lingkungan Maybank Indonesia Tangerang. Metode yang digunakan dalam penelitian ini bersifat assosiatif, yakni mengkaji pengaruh antara variabelindependen terhadap variabel independen. Pengumpulan data dilakukan dengan cara penyebaran angket (kuesioner) kepada populasi yang telah ditetapkan. Dalam hal ini, populasi penelitian adalah nasabah di lingkungan Maybank Indonesia Tangerang yang berjumlah 100 orang. Penentuan jumlah sampel dilakukan dengan teknikpurposiv (sengaja) terhadap populasi tersebut. Penulis mengajukan hipotesis, terdapat pengaruh Kualitas Produk, Suku Bunga dan Atribut Property secara bersama-sama terhadap Kepuasan Nasabah KPR di lingkungan Maybank Indonesia Tangerang.

Berdasar penelitian, dapat diperoleh hasil sebagai berikut: (a) secara parsial maupun simultan/bersama-sama variabel Kualitas Produk, variabelSuku Bunga dan variabelAtribut Property memiliki pengaruh yang signifikan terhadap variabelprofesionalisme auditor; (b) Besarnya pengaruh ketiga variabel (variabel Kualitas Produk, variabelSuku Bunga dan variabelsemangat kerja) terhadap variabelKepuasan Nasabah KPR adalah sebesar 59,9\%.

Berkenaan dengan hal-hal di atas, maka pimpinan organisasi hendaknya perlu mengupayakan: (a) Pimpinan perlu memperhatikan secara terus-menerus meningkatkan kualitas produk yang dihasilkan oleh organisasi, khususnya produk KPR. Dalam kaitan ini, untuk meningkatkan kualitas adalah memiliki spesifikasi yang sesuai dengan kebutuhan konsumen, sehingga menyebabkan konsumen merasa puas; (b) Pimpinan perlu senantiasa memperhatikan suku bunga yang berlaku terkait dengan pemberian KPR. Dalam hal ini, pimpinan perlu senantiasa memperhatikan lingkungan strategis yang sangat dinamis dalam kerangka penentuan suku bunga KPR; (c) Pengembang perumahan perlu untuk meningkatkan atau memperkaya atribut property terhadap perumahan atau hunian yang ditawarkan kepada para nasabah. Dalam kaitan ini, pihak perbankan dan pihak pengembang perumahan perlu berkoordinasi untuk merumuskan cara-cara (strategi) untuk menarik nasabah terhadap produk KPR yang ditawarkan perbankan dan pengembang perumahan. 


\section{PENDAHULUAN}

\subsection{Latar Belakang Masalah}

Manusia sebagai makhluk individu dan maupun sebagai makhluk sosial memiliki "kebutuhan" yang beraneka macam dalam menjalani kehidupannya sehari-hari. Kebutuhan adalah keinginan terhadap barang atau jasa yang harus dipenuhi, apabila tidak dipenuhi, maka akan menimbulkan dampak yang negatif. Berdasarkan tingkat kepentingannya, kebutuhan manusia ada 3 macam, yaitu kebutuhan primer, sekunder, dan tersier. Kebutuhan primer adalah kebutuhan yang harus dipenuhi untuk mempertahankan kelangsungan hidup manusia. Kebutuhan primer terdiri dari sandang (pakaian), pangan (makanan), dan papan (tempat tinggal). Kebutuhan sekunder adalah kebutuhan tambahan setelah kebutuhan pokok terpenuhi. Kebutuhan tersier adalah kebutuhan tambahan setelah kebutuhan primer dan sekunder terpenuhi. Kebutuhan tersier sering juga disebut kebutuhan akan barang mewah.

Untuk pemilihan produk perumahan, berdasarkan interview yang dilakukan dengan ahli properti dan konsumen, beberapa faktor yang menjadi pertimbangan konsumen dalam membeli rumah adalah Harga, Lokasi, Luas tanah, Jumlah Kamar, Keindahan Desain dan Fasilitas yang tersedia di luar dan di dalam rumah tersebut.Faktor harga sebuah rumah selalu berbanding lurus dengan fasilitas yang ada di dalam dan di luar rumah yang dikembangkan oleh pengembang. Bila fasilitas-fasilitasnya lengkap, tentu saja harganya lebih mahal. Demikian juga lokasi yang strategis akan mempengaruhi harga rumah. Karena selain harga, lokasi perumahan juga merupakan faktor penting dalam pemilihan rumah yang akan dibeli oleh calon pembeli. Lokasi yang lebih prestisius atau strategis menuntut harga yang lebih mahal, meskipun bagi sebagian konsumen yang memiliki cukup dana hal tersebut tidak menjadi masalah. Pertimbangan lokasi ketika ingin membeli rumah, biasanya agar dapat memudahkan pergi ke tempat bekerja, ke sekolah anak-anak atau dekat dengan sentra perniagaan. Lokasi ini juga biasanya meliputi bagaimana lingkungan di sekitar rumah tinggal, apakah mendukung bagi perkembangan anggota keluarga. Luas ruangan yang digambarkan pada jumlah kamar tidur juga faktor yang dipertimbangkan konsumen dalam menentukan perumahan yang akan dibeli. Faktor lain yang juga menjadi pertimbangan konsumen adalah keindahan desain, keunikan desain. Akhir-akhir ini, banyak perumahan yang dibangun dengan sebuah tema atau beberapa tema sekaligus. Misalnya: tema kampung bali, tema eropa, tema minimalis, tema mediterania, tema tradisional jawa dan lain sebagainya. Ada juga sebagian konsumen yang berpendapat bahwa yang terpenting dari sebuah rumah adalah rumah yang dapat memenuhi kebutuhan dalam beraktivitas dan peluang bisa tidaknya rumah tersebut dikembangkan dikemudian hari. Faktor terakhir yang dipertimbangkan konsumen adalah fasilitas apa saja yang ditawarkan oleh perumahan tersebut. Fasilitas ini biasanya mencakup: lebar jalan dan kondisi jalan di depan rumah yang merupakan salah satu hal yang cukup penting dan diperhatikan oleh calon pembeli.

Dalam konteks pemberian KPR bagi masyarakat/nasabah, sebagaimana disebutkan di atas pada saat ini terdapat banyak lembaga keuangan yang menyediakan jasa kepemilikan rumah. Salah satunya adalah PT BankMaybank Indonesia Tbk (d/h PT Bank Internasional IndonesiaTbk). Maybank Indonesia memberikan solusi bagi pihak yang membutuhkan hunian dengan cepat dan mudah.MaybankKredit Kepemilikan Properti (KPP) mencakup semua fasilitas kepemilikan properti yang terangkum di dalamnya.

Berkenaan dengan kegiatan pelayanan KPR di lingkungan Maybank Indonesia , pengamatanlangsung penulis di lapangan menggambarkan adanya fenomena-fenomena yang menarik untuk dibahas dalam sebuah tesis. Dalam hal ini, penulis akan menggali terkait dengan

kepuasan nasabah KPR di lingkunganMaybank Indonesia Tangerang.Hal ini menarik karena pada 
saat ini terjadi "persaingan" antar Bank dalam memberikan KPR kepada masyarakat yang mempunyai keinginan memiliki rumah.

\subsection{Identifikasi Masalah}

1. Masih kurangnya kemampuan atau keterampilan sebagian pegawai atau karyawan dalam mengerjakan serta menyelesaikan pekerjaan yang harus diemban. Dalam hal ini, menyebabkan pelayanan kepada nasabah seringkali kurang cepat, kurang tepat dan terlambat dalam penyelesaian pelayanannya.

2. Lamanya proses persetujuan atau approvaldari pihak Bank untuk proses KPR kepada para nasabah. Dalam kaitan ini, dalam pengurusan KPR dirasakan masih berbelit-belit dan prosedural, sehingga para nasabah membutuhkan waktu yang cukup lama dalam pengurusannya.

3. Masih lemahnya koordinasi atau kerjasama antar lini atau unit kerja di Maybank Indonesia Tangerang, sehingga menghambat kelancaran proses pengurusan atau pelayanan KPR kepada para nasabah.

4. Dinamika eksternal atau lingkungan luar sangat mempengaruhi kebijakan perbankkan, termasuk kebijakan dalam pemberian KPR. Hal ini menyebabkan perbankkan selalu dinamis juga dalam pengambilan kebijakan, termasuk pemberian KPR kepada masyarakat.

\subsection{Kerangka Berpikir}

Adapun visualisasikan model penelitian ini dapat digambarkan dalam bentuk kerangka berikut ini :

Variabel Bebas

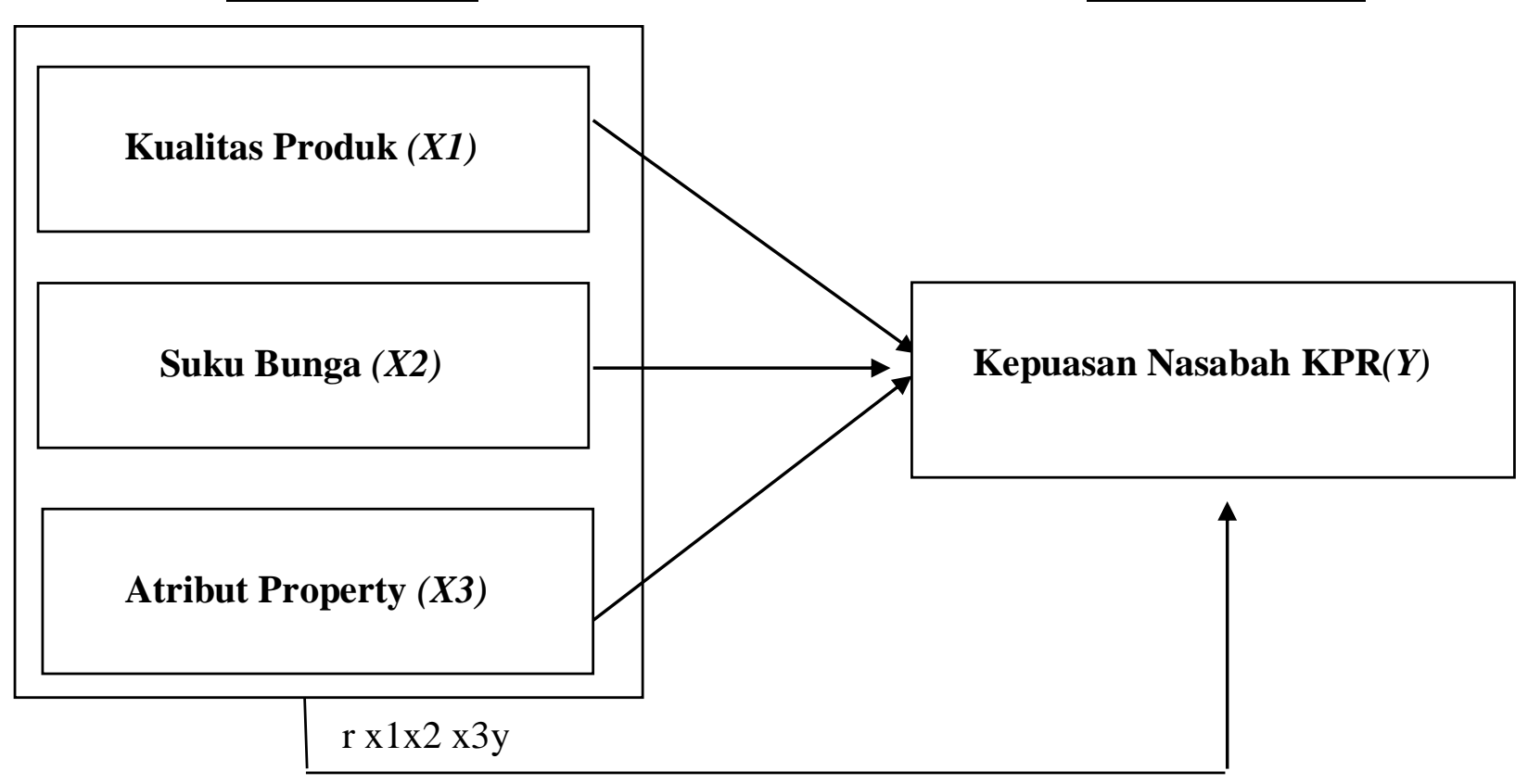

\subsection{Hipotesis Penelitian}

1. Diduga tidak ada pengaruh Kualitas Produk, Suku Bunga dan Atribut Property secara bersamasama terhadap Kepuasan Nasabah KPR di Maybank Indonesia Tangerang. 
2. Diduga ada pengaruh Kualitas Produk, Suku Bunga dan Atribut Property secara bersama-sama terhadap Kepuasan Nasabah KPR di Maybank Indonesia Tangerang.

\section{TINJAUAN PUSTAKA}

\subsection{Kualitas Produk}

Definisi Triguno (2012) menjelaskan bahwa kualitas adalah:

"........mempunyai dimensi tergantung pada produk yang diinginkan oleh pelanggan atau masyarakat antara lain seperti kinerja, bentuk, kesesuaian, kekuatan, pelayanan keindahan, rasa, harga, pemenuhan, kebutuhuan, kemanusiaan, keamanan, kemampuan dan lain-lain”.

Tingkat kualitas dapat digolongkan menjadi tiga (Triguno, 2012), yakni:

a. Sempurna atau terbaik;

b. Asal jadi, dan

c. Buruk.

Tingkat kualitas seperti tersebut di atas sangat relatif, karena tergantung kepada keputusan konsumen atau pihak yang berkepentingan sesuai dengan dimensi kualitas yang dikehendakinya. Semakin berkualitas, dapat berarti semakin minimnya cacat dan cela pada produk atau barang/jasa tersebut. Kualitas dapat berbentuk kualitatif maupun kuantitatif dan merupakan suatu kesepakatan dari kelompok/organisasi yang bersangkutan. Dengan kata lain, kualitas juga merupakan suatu standar yang harus dicapai oleh seseorang/kelompok/lembaga/perusahaanmengenai sumber daya manusia, kualitas cara kerja, proses, dan hasil kerja atau produk yang berupa barang dan jasa.

Tekait dengan kualitas produk menurut Kotler dan Amstrong (2011) menyatakan bahwa "The ability of a product to perform its functionts. It includes the product's overall durability, reliability, precision, ease of operation and repair, and other valued attributes", "Kemampuan sebuah produk untuk menjalankan fungsinya. Kemampuan ini secara menyeluruh termasuk daya tahan, keandalan, ketepatan, kemudahan operasi dan perbaikan, dan aspek-aspek nilai lainnya".

Lebih lanjut menurut Tjiptono (2010) ada enam macam dimensi kualitas produk, yaitu :

1. Kinerja (performance)

2. Keistimewaan tambahan (features)

3. Keandalan (reliability)

4. Kesesuaian spesifikasi (conformance to specifications)

5. Daya tahan (durability)

6. Estetika (aesthetic)

Klasifikasi produk pada umunya dapat dilakukan dengan berbagai cara. Salah satu cara yang banyak digunakan adalah klasifikasi berdasarkan daya tahan atau keberwujudan produk. Menurut Tjiptono (2003 ), ada tiga hal kelompok produk, yaitu :

1. Barang tahan lama (durable goods). Barang tahan lama adalah barang berwujud yang biasanya dapat bertahan lama dan memiliki unsur ekonomi lebih dari satu tahun. Contohnya lemari es, rumah, motor, mobil, radio, televisi dan mesin cuci.

2. Barang tidak tahan lama (nondurable goods). Barang tidak tahan lama merupakan berwujud yang biasanya habis dikonsumsi dalam satu atau beberapa kali pemakaian. Dengan kata lain, umur ekonominya kurang dari satu tahun. Contohnya sabun, minuman, makanan ringan, garam, gula, dan kapur tulis.

3. Jasa (service). Jasa adalah aktivitas, manfaat atau kepuasan yang ditawarkan untuk dijual. Contohnya bengkel reparasi, salon kecantikan, kursus keterampilan, hotel, rumah sakit dan sebagainya. 
Kualitas diperlukan dalam penyediaan produk atau jasa kepada pelanggan. Produk yang berkualitas adalah produk yang memiliki spesifikasi yang sesuai dengan kebutuhan konsumen sehingga menyebabkan konsumen merasa puas. Bagi perusahaan yang bergerak dibidang jasa, memuaskan kebutuhan pelanggan berarti perusahaan harus memberikan pelayanan yang berkualitas (service quality) kepada pelanggannya (Tony Wijaya, 2011).

\subsection{Pengertian KPR}

KPR (Kredit Pemilikan Rumah) adalah kredit yang digunakan untuk membeli rumah atau untuk kebutuhan konsumtif lainnya dengan jaminan/agunan berupa Rumah. Meskipun penggunaannya mirip, KPR berbeda dengan kredit konstruksi dan renovasi.Agunan yang diperlukan untuk KPR adalah rumah yang akan dibeli itu sendiri untuk KPR Pembelian. Sedangkan untuk KPR Multiguna atau KPR Refinancing yang menjadi Agunan adalah Rumah yang sudah dimiliki.

Karena masuk dalam kategori Kredit Konsumtif maka peruntukan KPR haruslah untuk kegiatan yang bersifat Konsumtif seperti pembelian rumah, furniture, kendaraan bermotor dan tidak diperbolehkan untuk kegiatan yang bersifat produktif seperti pembelian stok barang dagangan, modal kerja dan lain sebagainya.

\subsubsection{Produk KPR Maybank Indonesia}

Berkenaan dengan produk-produk yang dikeluarkan oleh PT Bank Maybank Indonesia Tbk (d/h PT Bank Internasional Indonesia Tbk) Konvensional dan Syariah dalam pemberian KPR, mereka memiliki beberapa produk unggulan yaitu :

1. Maybank KPR Ekpres Maybank, KPR Ekpres adalah fasilitas kredit yang diberikan Maybank untuk membiayai pembelian properti primary/secondary, dengan persetujuan prinsip 30 menit. Fasilitas ini dapat diberikan untuk pembiayaan pembelian rumah, apartemen, kavling, ruko/rukan, konstruksi/renovasi rumah dan take over KPR dari bank lain.

2. Rumah Maxima/Multiguna merupakan fasilitas yang ditujukan untuk meng-cover seluruh kebutuhan pribadi maupun keluarga. Maybank KPR Rumah Maxima dapat dipergunakan untuk membantu mengatasi kebutuhan biaya pendidikan, pengobatan, kredit mobil bahkan biaya pernikahan. Plafon kredit minimal sebesar 100 juta dengan jangka waktu pinjaman hingga 10 tahun. Maybank Rumah Maxima menyediakan solusi pembiayaan untuk pembelian kebutuhan setiap orang dan take over multiguna dari bank lain dengan jaminan rumah, apartemen, dan ruko.

3. Maybank KPR Floating rate merupakan layanan kredit yang memberikan perhitungan bunga dengan floating rate terendah sejak awal masa kredit, transparan dan fair berdasarkan BI Rate. Besaran suku bunga Maybank KPR Floating rate adalah BI Rate ditambah 3,5\%. Dengan produk KPR Floating rate nasabah akan lebih mudah mengetahui suku bunga yang harus dibayarkan. Misalnya BI Rate saat ini 7,5\% akan ditambahkan 3, 5\%, maka bunga KPR Floating rate yang harus dibayar nasabah sebesar $11 \%$. Keuntungan yang dapat diperoleh dari Maybank KPR Floating rate ialah bebas biaya penalti untuk waktu pelunasan kapan saja, bebas premi asuransi jiwa \& kesehatan.

4. Maybank KPR Bebas Bunga merupakan fasilitas KPR, yang dikombinasi dengan rekening tabungan, di mana saldo tabungan Setiap orang dan keluarga dapat menjadi faktor untuk mengurangi bunga cicilan KPR hingga menjadi bebas bunga. Jumlah dari rekening dapat mencapai maksimal hingga tujuh rekening.

5. Maybank KPR Fix 1 Tahun Up to 10 tahun, tersedia dalam dua pilihan yaitu, bunga fix sama dengan tenor pinjaman jadi misal nasabah menggunakan KPR Fix 10 tahun maka selama tenor pinjaman tersebut suku bunga yang dipakai sama terus. Jika menghendaki yang lain, nasabah 
juga dapat menggunakan produk bunga fix dengan tenor pinjaman berbeda, misal bunga fix 5 (lima) tahun untuk tenor pinjaman 7 (tujuh) tahun, maka selama 5 tahun bunga sama dan pada tahun selanjutnya akan menyesuaikan bunga umum.

6. Maybank Angsuran Tetap serta Maybank KPR Konstruksi-Renovasi adalah nasabah harus mengajukan aplikasi ditambah dengan denah bangunan dan Rencana Anggaran Belanja (RAB). Pencairan kredit Maybank konstruksi dan renovasi dilihat dari progress pembangunan.

\subsubsection{Suku Bunga}

Bunga adalah imbal jasa atas pinjaman uang.Imbal jasa ini merupakan suatu kompensasi kepada pemberi pinjaman atas manfaat ke depan dari uang pinjaman tersebut apabila diinvestasikan. Persentase dari pokok utang yang dibayarkan sebagai imbal jasa (bunga) dalam suatu periode tertentu disebut "suku bunga". Miller, RL dan Vanhoose, mengataka bahwa suku bunga adalah sejumlah dana, dinilai dalam uang, yang diterima si pemberi pinjaman (kreditor), sedangkan suku bunga adalah rasio dari bunga terhadap jumlah pinjaman.

Dalam konteks pengambilan KPR, beberapa hal yang perlu diperhatikan oleh nasabah/customer, khususnya terkait dengan cara penghitungan suku bunganya. Hal ini dikarenakan akan berpengaruh terhadap perbedaaan jumlah angsuran per bulan yang harus disetor kepada Bank. Adapun katagori penghitungan suku bunga dijelaskan sebagai berikut:

1. Bunga Flat

2. Bunga Efektif

3. Bunga Anuitas

4. Bunga Mengambang

\subsubsection{Atribut Property}

Definisi "atribut" memiliki beberapa arti, yaitu: sifat yang menjadi ciri khas (suatu benda atau orang); kategori variabel kualitatif (seperti laki-laki atau perempuan menunjukkan jenis kelamin); ciri atau sifat yang terdapat pada setiap benda purbakala, yang dapat dijadikan dasar untuk menentukan kelompok (Kamus Besar Bahasa Indonesia). Dengan demikian, dapat disederhanakan definisi atribut sebagai "sifat yang menjadi ciri khas (suatu benda atau orang)". Dalam kaitan ini, atribut merupakan ciri khas dari property/perumahan yang sedang dibahas dalam penelitian ini.

Kata properti berasal dari bahasa inggris "property" yang berarti sesuatu yangdapatdimilikiseseorang.MenurutWikipedia.com properti berarti kepemilikan seseorang terhadap suatu barang ataupun non barang.dewasa ini properti sering dikaitkan dengan rumah, perumahan ataupun hunian, padahal segala sesuatu yang sifatnya itu kepemilikan bisa disebut sebagai properti. apalagi barang tersebut terdaftar secara resmi dan memiliki surat-surat kepemilikan.Di Indonesia, istilah properti identik dengan real estate, rumah, tanah, ruko, gedung, atau gudang.

Menurut Kamus Besar Bahasa Indonesia (KBBI), propertidiartikan sebagai harta berupa tanah dan bangunan serta sarana dan prasarana yang merupakan bagian yang tidak terpisahkan dari tanah dan/atau bangunan yang dimaksudkan. Dengan demikian, disimpulkan pengertian properti merupakan tempat milik beserta bangunan.

Properti dapat bersifat barang, yaitu semua benda yang dimiliki oleh seseorang ataupun kelompok yang diakui secara sah oleh pihak lain (pemerintah) ataupun diakui sah secara adat. Sedangkan, properti yang bersifat bukan barang, yaitu semua karya yang dibuat oleh individu maupun kelompok, seperti karya ilmiah, dan ini sering disebut kekayaan ilmiah.

Dalam konteks penelitian ini, property dimaksudkan adalah bersifat barang yang dimiliki oleh seseorang atau kelompok orang yaitu perumahan.Hal ini mengacu pada UU No. 5 Tahun 1960 
Tentang Peraturan Dasar Pokok-Pokok Agraria, "Hak atas tanah dapat dimiliki oleh orang baik individu, kelompok maupun badan hukum.Hak-hak tersebut dapat dipergunakan untuk mempergunakan tanah yang bersangkutan". Adapun macam-macam hak atas tanah antara lain:

1. hak milik, Hak milik adalah hak turun menurun, terkuat dan terpenuh yang dapat dipunyai orang atas tanah. Hak milik dapat beralih dan dialihkan kepada orang lain.

2. hak guna-usaha, adalah hak untuk mengusahakan tanah yang dikuasai langsung oleh Negara, hak ini terjadi karena ketetapan pemerintah dimana memiliki jangka waktu tertentu.

3. hak guna-bangunan, adalah hak untuk mendirikan dan mempunyai bangunan-bangunan atas tanah yang bukan miliknya sendiri dengan jangka waktu tertentu.

4. hak pakai, adalah hak untuk menggunakan atau menggunakan hasil dari tanah yang dikuasai langsung oleh Negara atau tanah milik orang lain.

5. hak sewa, adalah hak untuk menggunakan atau menggunakan hasil dari tanah orang lain yang telah disewa.

Adanya perumahan perlu diatur dalam suatu peraturan yang mendasarinya. Dalam Pasal 4 UU Nomor 4 Tahun 1992 tentang Perumahan dan Permukiman, disebutkan bahwa penataan perumahan dan permukiman bertujuan untuk:

- Memenuhi kebutuhan rumah sebagai salah satu kebutuhan dasar manusia, dalam rangka peningkatan dan pemerataan kesejahteraan rakyat;

- Mewujudkan perumahan dan permukiman yang layak dalam lingkungan yang sehat, aman, serasi, dan teratur;

- Memberi arah pada pertumbuhan wilayah dan persebaran penduduk yang rasional;

- Menunjang pembangunan di bidang ekonomi, sosial, budaya, dan bidang-bidang lain.

Hal sama mengenai persyaratan lokasi permukiman juga dijelaskan Joseph De Chiara (2012), dimana beberapa elemen yang harus dipertimbangkan dalam pemilihan perumahan tapak untuk perumahan apabila ingin dicapai pembangunan dan pemeliharaan yang sehat, antara lain:

1. Kondisi tanah dan bawah tanah.

2. Air tanah dan drainase

3. Keterbebasan dari banjir permukaan

4. Kesesuaian penapakan bangunan yang akan direncanakan

5. Kesesuaian untuk akses dan sirkulasi

6. Kesesuaian untuk pembangunan ruang terbuka

7. Keterbatasan dari bahaya kecelakaan topografi berikut;

Menurut Zulfie Syarief (2010), beberapa kriteria perumahan yang layak adalah sebagai

1. Jaminan perlindungan hukum. Perlindungan hukum mengambil banyak bentuk, diantaranya penyewaan akomodasi (publik dan swasta), perumahan kolektif, kredit, perumahan darurat, pemukiman informal, termasuk penguasaan tanah dan properti.

2. Ketersediaan layanan, bahan-bahan baku, fasilitas, dan infra struktur. Tempat tinggal yang layak harus memiliki fasilitas tertentu yang penting bagi kesehatan, keamanan, kenyamanan, dan nutrisi.

3. Keterjangkauan. Biaya pengeluaran seseorang atau rumah tangga yang bertempat tinggal harus pada tingkat tertentu dimana pencapaian dan pemenuhan terhadap kebutuhan dasar lainnya tidak terancam atau terganggu. Tindakan harus diambil oleh Negara Pihak untuk memastikan bahwa persentasi biaya yang berhubungan dengan tempat tinggal, secara umum sepadan dengan tingkat pendapatan.

4. Layak huni. Tempat tinggal yang memadai haruslah layak dihuni, artinya dapat menyediakan ruang yang cukup bagi penghuninya dan dapat melindungi mereka dari cuaca dingin, lembab, 
panas,hujan, angin, atau ancaman-ancaman bagi kesehatan, bahaya fisik bangunan, dan vektor penyakit. Keamanan fisik penghuni harus pula terjamin.

5. Aksesibilitas. Tempat tinggal yang layak harus dapat diakses oleh semua orang yang berhak atasnya. Kelompok-kelompok yang kurang beruntung seperti halnya manula, anak-anak, penderita cacat fisik, penderita sakit stadium akhir, penderita HIV-positif, penderita sakit menahun, penderita cacat mental, korban bencana alam, penghuni kawasan rawan bencana, dan lain-lain harus diyakinkan mengenai standar prioritas untuk lingkungan tempat tinggal mereka.

6. Lokasi.Tempat tinggal yang layak harus berada di lokasi yang terbuka terhadap akses pekerjaan, pelayanan kesehatan, sekolah, pusat kesehatan anak, dan fasilitas-fasilitas umum lainnya. Di samping itu, rumah hendaknya tidak didirikan di lokasi-lokasi yang telah atau atau akan segera terpolusi, yang mengancam hakuntuk hidup sehat para penghuninya.

7. Kelayakan budaya. Cara rumah didirikan, bahan baku bangunan yang digunakan, dan kebijakan-kebijakan yang mendukung kedua unsur tersebut harus memungkinkan pernyataan identitas budaya dan keragaman tempat tinggal.

\subsection{Kepuasan Nasabah KPR}

Oxford Advanced Learner's Dictionary (Tjiptono dan Gregorius, 2011) mendeskripsikan kepuasan adalah perasaan baik ketika anda mendapatkan sesuatu atau ketika sesuatu yang anda ingin terjadi tidak terjadi, tindakan memenuhi kebutuhan atau keinginan. Menurut Oliver, kepuasan adalah tingkat perasaan seseorang (konsumen) setelah membandingkan antara kinerja atau hasil yang dirasakan (pelayanan yang diterima dan dirasakan) dengan yang diharapkannya (Irine, 2012).

Engel, Roger dan Miniard (2013) mengatakan bahwa kepuasan adalah evaluasi paska konsumsi untuk memilih beberapa alternatif dalam rangka memenuhi harapan. Band (dalam Nasution, 2011) mengatakan bahwa kepuasan tercapai ketika kualitas memenuhi dan melebihi harapan, keinginan dan kebutuhan konsumen. Sebaliknya, bila kualitas tidak memenuhi dan melebihi harapan, keinginan dan kebutuhan konsumen maka kepuasan tidak tercapai. Konsumen yang tidak puas terhadap barang atau jasa yang dikonsumsinya akan mencari perusahaan lain yang mampu menyediakan kebutuhannya.Selanjutnya menurut Fandy Tjiptono (2011), kepuasan konsumen mencakup perbedaan antara harapan dan kinerja atau hasil yang dirasakan.

Lupiyoadi (2011) menyebutkan lima faktor utama yang perlu diperhatikan dalam kaitannya dengan kepuasan konsumen, antara lain :

1. Kualitas produk

2. Kualitas pelayanan

3. Emosional

4. Harga

5. Biaya

Sedangkan menurut Zeithaml dan Bitner (2012) mengemukakan bahwa kepuasan konsumen dipengaruhi oleh beberapa faktor berikut :

1. Kualitas pelayanan

2. Kualitas produk

3. Harga

4. Faktor situasi dan personal

Sementara itu, kotler dan keller (2013) menyebutkan terdapat beberapa faktor yang mempengaruhi kepuasan pelanggan, yaitu: 
1. Harapan pelanggan yang diyakini memiliki peranan besar dalam menentukan kualitas produk dan kepuasan pelanggan. Dalam mengevaluasi, pelanggan akan menggunakan harapannya sebagai standar atau acuan.

2. Tujuan (objective) dikaitkan dengan kebutuhan yang paling mendasar, tujuan hidup atau keinginan yang lebih konkrit menurut kepercayaan seseorang dalam pencapaian tujuan akhir. Jadi tingkat keinginan yang lebih rendah atau lebih tinggi dapat dihubungkan dengan cara untuk mencapai tujuan.

3. Perceived performance, merupakan hasil evaluasi dari pengalaman konsumsi sekarang dan diharapkan memiliki pengaruh langsung dan positif terhadap overall customer satisfaction. Sedangkan, komponen utama dari consumption experience adalah: (a) kebiasaan; dan (b) reliabilitas.

Atribut Satisfaction dan information satisfaction, didefinisikan sebagai pertimbangan kepuasan konsumen yang subyektif yang dihasilkan dari observasi mengenai kinerja produk. Dalam mengevaluasi kepuasan terhadap produk atau perusahaan tertentu, konsumen umumnya mengacu pada beberapa faktor atau dimensi.

\section{METODE PENELITIAN}

\subsection{DesainPenelitian}

Pendekatan penelitian yang digunakan adalah pendekatan penelitian kuantitatif. Pendekatan kuantitatif adalah pendekatan penelitian yang secara primer menggunakan paradigma postpositivist dalam mengembangkan ilmu pengetahuan (seperti pemikiran tentang sebab akibat, reduksi kepada variabel, hipotesis, pertanyaan spesifik, menggunakan pengukuran dan observasi, serta pengujian teori) menggunakan strategi penelitian seperti eksperimen dan survai yang memerlukan data statistik(Emzir, 2012), Sedangkan, Prasetya Irawan (2013) menjelaskan bahwa dalam konteks ilmu eksakta, kuantitas jelas sekali berhubungan dengan angka (kuantita), baik hasil pengukurannya, analisis data maupun penarikan kesimpulannya semua dalam bentuk angka.

Berdasarkan metodenya penelitian ini dapat digolongkan sebagai penelitian survai (survey research). Menurut M. Iqbal Hasan (2012), penelitian survai adalah penelitian yang diadakan untuk memperoleh fakta-fakta dari gejala-gejala yang ada dan mencari keterangan-keterangan secara faktual, baik tentang institusi sosial, ekonomi, atau politik dari suatu kelompok ataupun suatu daerah.

Sementara itu, berdasarkan tingkat eksplanasinya, penelitian ini merupakan penelitian assosiatif.Penelitian yang bersifat assosiatif atau korelasional adalah penelitian yang bertujuan menjelaskan hubungan kausalitas (sebab-akibat) antara dua variabel atau lebih (Prasetya Irawan, 2012).Dalam hal ini, penelitian akan menjelaskan tentang hubungan atau pengaruh variabel-variabel Kualitas Produk, Suku Bunga dan Atribut Property terhadap Kepuasan Nasabah KPR di PT Bank Maybank Indonesia Tbk Cabang Tangerang. 


\subsection{Definisi Operasional Variabel}

Variabel-variabel yang digunakan dalam penelitian ini adalah menggunkan 3 Variabel bebas dan 1 Variabel terikat:

1. Variabel bebas independent variable) merupakan variable yang mempengaruhi atau menjadi sebab timbulnya variabele dependent (terikat). Sebagai variable bebas dalam penelitian ini adalah Kualaitas Produk, Suku Bunga, dan Atribut Property.

2. Variable terikat (dependent variable) merupakan variabel yang dipengaruhi atau yang menjadi akibat karena adanya variable bebas. Dalam penelitian ini yang menjadi variable terikat (dependent variable ) adalah Kepuasan Nasabah Maybank Indonesia Cabang Tangerang. 
Variabel dan Indikator Kualitas Produk

\begin{tabular}{|c|c|c|}
\hline Variabel & Indikator & $\begin{array}{c}\begin{array}{c}\text { Nomer Pada } \\
\text { Kuesioner }\end{array} \\
\end{array}$ \\
\hline \begin{tabular}{l}
\multicolumn{1}{c}{ Kualitas Produk } \\
$\qquad$ (X1 ) \\
Suatu kondisi dari segala \\
sesuatu yang ditawarkan \\
kepada konsumen baik yang \\
barang berwujud (dapat \\
diraba/tangible) atau tidak \\
berwujud (tidak dapat \\
diraba/intangible) untuk \\
memenuhi sebuah keinginan \\
atau kebutuhan.
\end{tabular} & $\begin{array}{ll}\text { - } & \text { Kinerja (performance) } \\
\text { - } & \text { Keistimewaan tambahan (features) } \\
\text { - } & \text { Keandalan (reliability) } \\
\text { - } & \text { Kesesuaian spesifikasi (conformance to } \\
& \text { specifications) } \\
\text { - } & \text { Daya tahan (durability) } \\
\text { - } & \text { Estetika (aestetic) }\end{array}$ & $\begin{array}{l}\text { Soal No } 1 \\
\text { Soal No } 2 \\
\text { Soal No } 3 \\
\text { Soal No } 4 \\
\text { Soal No } 5 \\
\text { Soal No } 6 \\
\text { Soal No } 7 \\
\text { Soal No } 8 \\
\text { Soal No } 9 \\
\text { Soal No10 } \\
\text { Soal No } 11 \\
\text { Soal No } 12 \\
\text { Soal No } 13 \\
\text { Soal No } 14 \\
\text { Soal No } 15\end{array}$ \\
\hline
\end{tabular}

Variabel dan Indikator Suku Bunga

\begin{tabular}{|c|c|c|}
\hline Variabel & Indikator & $\begin{array}{c}\text { Nomer Pada } \\
\text { Kuesioner }\end{array}$ \\
\hline $\begin{array}{l}\text { Suku Bungan } \\
\qquad(\mathrm{X} 2) \\
\text { Merupakan persentase dari pokok hutang } \\
\text { yang dibayarkan sebagai imbal jasa } \\
\text { (bunga) dalam suatu periode tertentu. }\end{array}$ & $\begin{array}{ll}- & \text { Bunga Flat } \\
\text { - } & \text { Bungan Efektif } \\
\text { - } & \text { Bunga Anuitas } \\
& \text { Bunga Mengambang }\end{array}$ & $\begin{array}{l}\text { Soal No } 1 \\
\text { Soal No } 2 \\
\text { Soal No } 3 \\
\text { Soal No } 4 \\
\text { Soal No } 5 \\
\text { Soal No } 6 \\
\text { Soal No } 7 \\
\text { Soal No } 8 \\
\text { Soal No 9 } \\
\text { Soal No10 } \\
\text { Soal No } 11 \\
\text { Soal No } 12 \\
\text { Soal No } 13 \\
\text { Soal No } 14 \\
\text { Soal No } 15\end{array}$ \\
\hline
\end{tabular}


Variabel dan Indikator Atribut Produk

\begin{tabular}{|c|c|c|}
\hline Variabel & Indikator & $\begin{array}{c}\text { Nomer Pada } \\
\text { Kuesioner }\end{array}$ \\
\hline $\begin{array}{l}\text { Atribut Property } \\
\qquad \text { ( X3 ) } \\
\text { Suatu ciri atau sifat yang dimiliki oleh } \\
\text { kelompok rumah yang berfungsi sebagai } \\
\text { lingkungan tempat tinggal atau } \\
\text { lingkungan hunian yang dilengkapi } \\
\text { dengan prasarana dan sarana lingkungan. }\end{array}$ & $\begin{array}{l}\text { - Jaminan perlindungan } \\
\text { hukum } \\
\text { - Ketersediaan layanan, } \\
\text { bahan-bahan baku, } \\
\text { fasilitas, dan infra } \\
\text { struktur } \\
\text { - Keterjangkauan } \\
\text { - Layak huni } \\
\text { - Aksesibilitas } \\
\text { - Lokasi } \\
\text { - Kelayakan budaya }\end{array}$ & $\begin{array}{l}\text { Soal No } 1 \\
\text { Soal No } 2 \\
\text { Soal No } 3 \\
\text { Soal No } 4 \\
\text { Soal No } 5 \\
\text { Soal No } 6 \\
\text { Soal No } 7 \\
\text { Soal No } 8 \\
\text { Soal No } 9 \\
\text { Soal No10 } \\
\text { Soal No } 11 \\
\text { Soal No } 12 \\
\text { Soal No } 13 \\
\text { Soal No } 14 \\
\text { Soal No } 15\end{array}$ \\
\hline
\end{tabular}

\section{Variabel dan Indikator Kepuasan Nasabah}

\begin{tabular}{|c|c|c|}
\hline Variabel & Indikator & $\begin{array}{c}\text { Nomer Pada } \\
\text { Kuesioner }\end{array}$ \\
\hline \begin{tabular}{l}
\multicolumn{1}{c}{ Kepuasan Nasabah } \\
$\qquad$ ( Y ) \\
Merupakan tingkat perasaan \\
seseorang (nasabah) setelah \\
membandingkan antara \\
kinerja atau hasil yang \\
dirasakan (pelayanan yang \\
diterima dan dirasakan) \\
dengan yang diharapkannya.
\end{tabular} & $\begin{array}{l}\text { - Harapan nasabah } \\
\text { - Tujuan/objective } \\
\text { - } \text { Perceived performance } \\
\text { - Atribut Satisfaction dan information } \\
\text { satisfaction. }\end{array}$ & $\begin{array}{l}\text { Soal No } 1 \\
\text { Soal No } 2 \\
\text { Soal No } 3 \\
\text { Soal No } 4 \\
\text { Soal No } 5 \\
\text { Soal No } 6 \\
\text { Soal No } 7 \\
\text { Soal No } 8 \\
\text { Soal No } 9 \\
\text { Soal No10 } \\
\text { Soal No } 11 \\
\text { Soal No } 12 \\
\text { Soal No } 13 \\
\text { Soal No } 14 \\
\text { Soal No } 15\end{array}$ \\
\hline
\end{tabular}

\subsection{Populasi dan Sampel}

\subsubsection{Populasi}

Menurut Irawan (2012), populasi adalah keseluruhan elemen yang akan diteliti/dipelajari oleh seorang Peneliti di dalam penelitiannya. Populasi bukan sekedar jumlah yang ada pada obyek/subyek yang diteliti, tetapi meliputi seluruh karakteristik/sifat yang dimiliki oleh obyek atau 
subyek itu. Dalam penelitian ini, populasi adalah pelanggan (nasabah) di Maybank Indonesia Tangerang. Populasi dalam penelitian ini dikhususkan pada nasabah Maybankyang mengajukan KPRpadabulanJuli 2015 sampaidenganbulan September 2015di Maybank Indonesia Tangerang

\subsubsection{Sampel}

Sugiyono (2011) menjelaskan bahwa sampel adalah "sebagian dari jumlah dan karakteristik yang dimiliki oleh populasi tersebut". Dalam penelitian ini, sampel ditentukan secara purpossive (sengaja) terhadap nasabah KPR di Maybank Indonesia Cabang Tangerang. Penentuan jumlah sampel penelitian dengan teknik purpossive atau sengaja ini dilakukan dengan menentukan jumlah sampel sebanyak 100 nasabah/responden.

\subsection{Teknik dan Alat Pengumpulan Data}

\subsubsection{Metode Pengumpulan Data}

Dalam setiap penelitian diperlukan data atau informasi sebagai bahan untuk melakukan kajian/pembahasan terhadap fenomena yang diteliti. Dalam hal ini, peneliti mengumpulkan data dengan dua cara, yaitu: studikepustakaandanpenelitian lapangan (penyebaran kuesioner).

1. Studi Kepustakaan.

2. Penyebaran Kuesioner.

\subsubsection{Jenis dan Sumber Data}

Sebagai bahan untuk menganalisis terhadap permasalahan yang akan ditelaah, maka dibutuhkan data-data dan informasi-informasi. Dalam hal ini, jenis data penelitian adalah data primer dan data sekunder. Data primer diperoleh melalui penyebaran kuesioner kepada sampel atau responden yang telah ditentukan sebelumnya (nasabah KPR). Sedangkan, data sekunder diperoleh melalui penelusuran dokumen-dokumen, naskah-naskah, dan referensi-referensi lain yang relevan dengan penelitian ini.

\subsection{Teknik Analisis Data}

\subsubsection{Uji Persyaratan Analisis}

Uji persyaratan analisis yaitu terdiri dari :

1. Uji Validitas Data

2. Uji Reliabilitas Data

3. UjiNormalitas Data

\subsubsection{Uji Asumsi Klasik}

Apabila telah diperoleh model regresi, sebelum dilakukan analisis keterpengaruhan (regresi), maka model regresi tersebut harus BLUE (Best Linier Unbiased Estimator). Persyaratan-persyaratan yang harus dipenuhi antara lain adalah:

1. Uji Multikolinearitas

2. UjiAutokorelasi

3. Uji Heteroskedastisitas 


\subsubsection{Uji Persyaratan Hipotesis}

1. Analisis Regresi Linier Berganda

2. Uji Statistik t (Uji Signifikan Parameter Individual)

3. Uji Statistik F (Uji Signifikan Simultan)

4. Uji R2

\section{PEMBAHASAN}

\section{Analisis Keterpengaruhan (Regresi) Parsial}

\section{a. Pengaruh Kualitas Produk terhadap Kepuasan Nasabah KPR}

Pengaruh Kualitas Produk terhadap Kepuasan Nasabah KPR

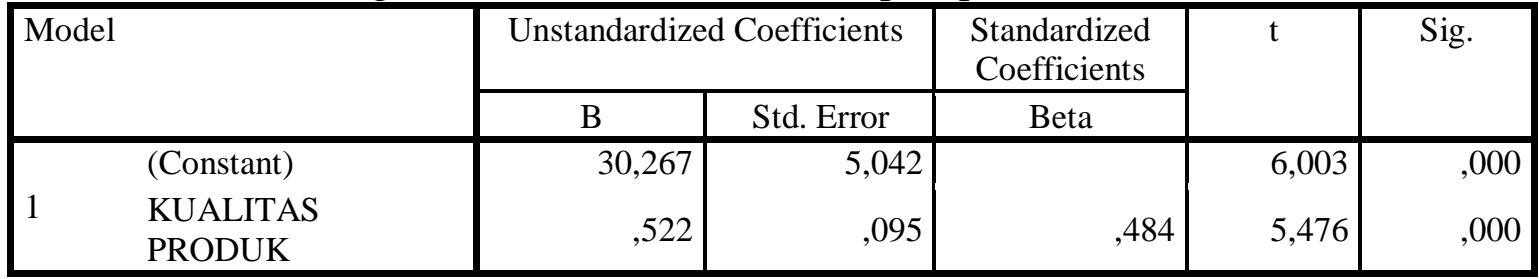

a. Dependent Variable: KEPUASAN NASABAH KPR

Sumber : Hasil Perhitungan SPSS, 2015

Hasil perhitungan analisis tersebut di atas dapat membentuk persamaaan regresi parsial sebagai berikut:

$$
\mathrm{Y}=30,267+0,522 \mathrm{X} 1
$$

Persamaan di atas memiliki arti sebagai berikut :

1) Variabel Kepuasan Nasabah KPR mempunyai nilai (konstanta) sebesar 30,267, apabila Variabel $\mathrm{X} 1$ (Kualitas Produk) memiliki nilai 0 (nol) atau tidak berpengaruh.

2) Variabel X1 (Kualitas Produk) mempunyai nilai sebesar 0,522, yang berarti apabila variabel X1 bertambah satu satuan akan menambah pengaruh sebesar 0,522terhadap variabel Y (Kepuasan Nasabah KPR ).

\section{b. Pengaruh Suku Bunga terhadap Kepuasan Nasabah KPR}

Pengaruh Suku Bunga terhadap Kepuasan Nasabah KPR

\begin{tabular}{|c|c|c|c|c|c|}
\hline \multirow[t]{2}{*}{ Model } & \multicolumn{2}{|c|}{$\begin{array}{l}\text { Unstandardized } \\
\text { Coefficients }\end{array}$} & $\begin{array}{l}\text { Standardized } \\
\text { Coefficients }\end{array}$ & \multirow[t]{2}{*}{$\mathrm{t}$} & \multirow[t]{2}{*}{ Sig. } \\
\hline & $\mathrm{B}$ & Std. Error & Beta & & \\
\hline (Constant) & 18,371 & 4,023 & & 4,566 &, 000 \\
\hline $\begin{array}{l}\text { SUKU } \\
\text { BUNGA }\end{array}$ & ,741 &, 075 &, 705 & 9,836 & ,000 \\
\hline
\end{tabular}

a. Dependent Variable: KEPUASAN NASABAH KPR

Sumber : Hasil Perhitungan SPSS, 2015

Hasil perhitungan analisis tersebut di atas dapat membentuk persamaaan regresi parsial sebagai berikut: 


$$
\mathrm{Y}=18,371+0,741 \mathrm{X} 2
$$

Persamaan di atas memiliki arti sebagai berikut :

1) Variabel Kepuasan Nasabah KPR mempunyai nilai (konstanta) sebesar 18,371, apabila Variabel X2 (Suku Bunga) memiliki nilai 0 (nol) atau tidak berpengaruh.

2) Variabel $\mathrm{X} 2$ (Suku Bunga) mempunyai nilai sebesar 0,741, yang berarti apabila variabel $\mathrm{X} 2$ bertambah satu satuan akan menambah pengaruh sebesar 0,741terhadap variabel Y (Kepuasan Nasabah KPR).

\section{c. Pengaruh Atribut Property terhadap Kepuasan Nasabah KPR}

Pengaruh Atribut Property terhadap Kepuasan Nasabah KPR

\begin{tabular}{|c|c|c|c|c|c|c|}
\hline \multirow{2}{*}{\multicolumn{2}{|c|}{ Model }} & \multicolumn{2}{|c|}{ Unstandardized Coefficients } & Standardized & \multirow[t]{2}{*}{$\mathrm{t}$} & \multirow[t]{2}{*}{ Sig. } \\
\hline & & B & Std. Error & Beta & & \\
\hline \multirow[b]{2}{*}{1} & (Constant) & 17,832 & 5,581 & & 3,195 &, 002 \\
\hline & $\begin{array}{l}\text { ATRIBUT } \\
\text { PROPERTY }\end{array}$ & ,739 & 103 & ,587 & 7,175 & ,000 \\
\hline
\end{tabular}

a. Dependent Variable: KEPUASAN NASABAH KPR

Sumber : Hasil Perhitungan SPSS, 2015

Hasil perhitungan analisis tersebut di atas dapat membentuk persamaaan regresi parsial sebagai berikut:

$$
\mathrm{Y}=17,832+0,739 \mathrm{X} 3
$$

Persamaan di atas memiliki arti sebagai berikut :

1) Variabel Kepuasan NasabahKPR mempunyai nilai (konstanta) sebesar 17,832, apabila Variabel X3 (Atribut Property) memiliki nilai 0 (nol) atau tidak berpengaruh.

2) Variabel X3 (Atribut Property) mempunyai nilai sebesar 0,739, yang berarti apabila variabel X3 bertambah satu satuan akan menambah pengaruh sebesar 0,739 terhadap variabel Y (Kepuasan Nasabah KPR).

\section{Analisis Keterpengaruhan (Regresi) Ganda}

Pengaruh Kualitas Produk,Suku Bunga danAtribut Property

\begin{tabular}{|c|c|c|c|c|c|c|}
\hline \multirow{2}{*}{\multicolumn{2}{|c|}{ Model }} & \multicolumn{2}{|c|}{ Unstandardized Coefficients } & \multirow{2}{*}{$\begin{array}{c}\begin{array}{c}\text { Standardize } \\
\mathrm{d} \\
\text { Coefficients }\end{array} \\
\text { Beta }\end{array}$} & \multirow[t]{2}{*}{$\mathrm{t}$} & \multirow[t]{2}{*}{ Sig. } \\
\hline & & B & Std. Error & & & \\
\hline \multirow{4}{*}{1} & (Constant) & ,857 & 5,090 & & , 168 & ,867 \\
\hline & $\begin{array}{l}\text { KUALITAS } \\
\text { PRODUK }\end{array}$ & , 162 & ,080 &, 150 & 2,022 & ,046 \\
\hline & SUKU BUNGA &, 514 & 083 & ,488 & 6,150 &, 000 \\
\hline & $\begin{array}{l}\text { ATRIBUT } \\
\text { PROPERTY }\end{array}$ & ,391 & ,093 & 310 & 4,206 &, 000 \\
\hline
\end{tabular}

Terhadap Kepuasan Nasabah KPR

Sumber : Hasil Perhitungan SPSS, 2015 
Berdasarkan hasil analisis tersebut di atas dapat membentuk persamaaan regresi ganda sebagai berikut:

$$
\mathrm{Y}=0,857+0,163 \mathrm{X} 1+0,514 \mathrm{X} 2+0,391 \mathrm{X} 3
$$

Persamaan di atas memiliki arti sebagai berikut :

a. Variabel Kepuasan Nasabah KPR mempunyai nilai (konstanta) sebesar 0,857 apabila Variabel X1 (Kualitas Produk),Variabel X2 (Suku Bunga) dan Variabel X3 (Atribut Property) memiliki nilai 0 (nol) atau tidak berpengaruh.

b. Variabel X1 (Kualitas Produk) mempunyai nilai sebesar 0,162, yang berarti apabila variabel X1 bertambah satu satuan akan menambah pengaruh sebesar 0,163terhadap variabel Y (Kepuasan Nasabah KPR).

c. Variabel X2 (Suku Bunga) mempunyai nilai sebesar 0,514, yang berarti apabila variabel X2 bertambah satu satuan akan menambah pengaruh sebesar 0,514terhadap variabel Y (Kepuasan Nasabah KPR).

d. Variabel X3 (Atribut Property) mempunyai nilai sebesar 0,391, yang berarti apabila variabel X3 bertambah satu satuan akan menambah pengaruh sebesar 0,391terhadap variabel Y (Kepuasan Nasabah KPR).

Sementara itu, untuk melihat besarnya pengaruh ketiga variabel independen terhadap variabel dependen, maka dapat dilihat dari tabel di bawah ini:

Kesimpulan Hasil Regresi

\begin{tabular}{|l|r|r|r|r|r|}
\hline Model & \multicolumn{1}{|c|}{$\mathrm{R}$} & $\mathrm{R}$ Square & $\begin{array}{c}\text { Adjusted R } \\
\text { Square }\end{array}$ & $\begin{array}{c}\text { Std. Error of } \\
\text { the Estimate }\end{array}$ & $\begin{array}{c}\text { Durbin- } \\
\text { Watson }\end{array}$ \\
\hline 1 &, $774^{\mathrm{a}}$ &, 599 &, 586 & 3,67235 & 2,304 \\
\hline
\end{tabular}

a. Predictors: (Constant), ATRIBUT PROPERTY, KUALITAS PRODUK,

SUKU BUNGA

b. Dependent Variable: KEPUASAN NASABAH KPR

Sumber : Hasil Perhitungan SPSS, 2015

Dari hasil perhitungan statistik di atas, maka dapat diuraikan penjelasan sebagai berikut : Nilai r Square (r determinan) sebesar 0,599memberikan arti bahwa Variabel Independen (Kualitas Produk, Suku Bunga dan Atribut Property) mempunyai pengaruh sebesar 59,9\% terhadap Variabel Dependent (Kepuasan Nasabah KPR)Sedangkan, sisanya sebesar 40,1\% dipengaruhi oleh variabelvariabel lain yang tidak dibahas dalam penelitian ini. Dalam kaitan ini, faktor-faktor lain yang kemungkinan besar dapat mempengaruhi Kepuasan Nasabah KPR adalah, seperti: persyaratanpersyaratan peminjaman, pelayanan perbankkan dan lain sebagainya.

\section{Uji-F}

Sebagaimana dijelaskan sebelumnya untuk menguji tingkat signifikansi pengaruh variabel independen terhadap variabel dependen secara bersama-sama (regresi ganda), maka digunakan Uji-F atau F-test.Secara terperinnci, hasil perhitungan statistik memperlihatkan besarnya nilai $\mathrm{F}$ hitung seperti pada tabel di bawah ini: 


\section{Kesimpulan Hasil Regresi}

\begin{tabular}{|rl|r|r|r|r|r|}
\hline Model & Sum of Squares & \multicolumn{1}{c|}{ df } & Mean Square & F & Sig. \\
\hline \multirow{3}{*}{1} & Regression & 1932,570 & 3 & 644,190 & 47,767 &, $000^{\mathrm{b}}$ \\
& Residual & 1294,670 & 96 & 13,486 & & \\
& Total & 3227,240 & 99 & & & \\
\hline
\end{tabular}

a. Dependent Variable: KEPUASAN NASABAH KPR

b. Predictors: (Constant), ATRIBUT PROPERTY, KUALITAS PRODUK, SUKU BUNGA

Sumber: Hasil Pengolahan Data dengan SPSS, 2012.

Berdasarkan hasil perhitungan pada tabel di atas, diperoleh hasil nilai F- hitung sebesar 47,767, dengan derajat bebas atau degree of freedom (df) untuk regression sebesar 3 dan untuk residual sebesar 96. Sedangkan, nilai probabilitas (Sig) pada uji F lebih kecil daripada 0,5. Ini berarti: Ho ditolak dan Ha diterima. Dengan demikian, ketiga variabelbebas (Kualitas Produk, Suku Bunga dan Atribut Property) secara bersama-sama mempunyai pengaruh yang signifikan terhadap Kepuasan Nasabah KPR. Selain itu, persamaan regresi berganda yang digunakan dalam penelitian ini dapat digunakan untuk memprediksi perubahan Kepuasan Nasabah KPR atau dapat dikatakan bahwa persamaan model regresi terbentuk secara linier.

\section{Uji Normalitas}

Untuk menguji normalitas pengaruh antara variabel Kualitas Produk, variabel Suku Bunga dan variabel Atribut Property terhadap variabel Kepuasan Nasabah KPR dapat diperhatikan dari hasil analisis atau uji normalitas yang ditunjukkan pada gambar di bawah ini:

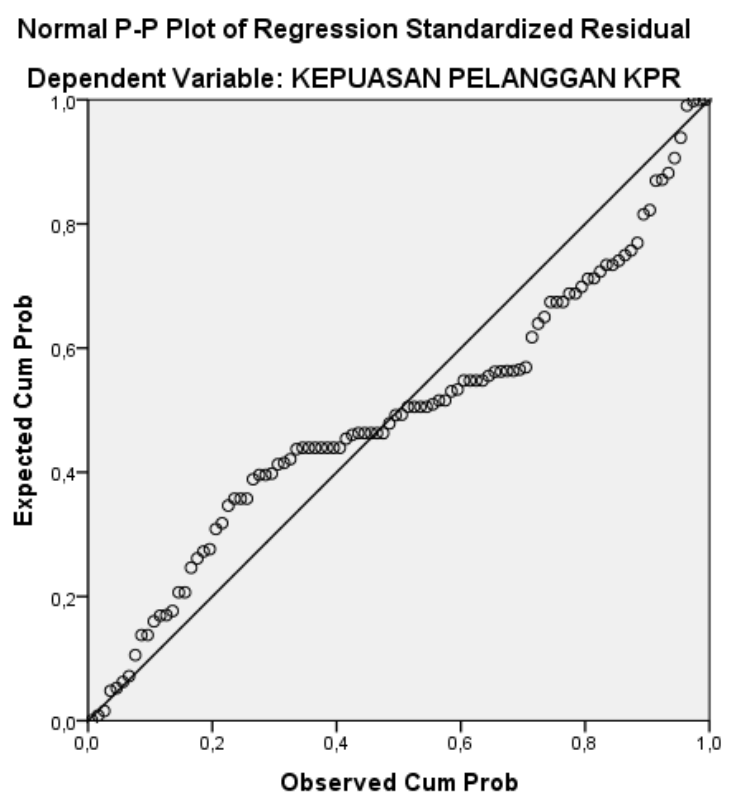

Gambar Uji Normalitas

Sumber : Hasil Perhitungan SPSS, 2015

Berdasarkan analisis atau uji normalitas memperlihatkan bahwa titik-titik data membentuk pola garis lurus, sehingga asumsi kenormalan terpenuhi. 


\section{Uji Multikolinearitas}

Multikolinearitas adalah untuk menguji ada tidaknya hubungan linear yang "sempurna" (pasti) diantara beberapa atau semua variabel independen dari model regresi. Bila hubungan antara variabel independen sangat tinggi, umumnya akan terjadi multikolinearitas. Pada umumnya jika VIF (Variance Inflation Factor) kurang dari 5, maka variabel independen tersebut mempunyai persoalan dengan variabel independen lainnya.

Kesimpulan Hasil Regresi

\begin{tabular}{|c|c|c|c|c|c|c|c|c|}
\hline \multirow{2}{*}{\multicolumn{2}{|c|}{ Model }} & \multicolumn{2}{|c|}{$\begin{array}{l}\text { Unstandardized } \\
\text { Coefficients }\end{array}$} & \multirow{2}{*}{$\begin{array}{c}\text { Standardized } \\
\text { Coefficients }\end{array}$} & \multicolumn{2}{|c|}{$\begin{array}{c}95,0 \% \\
\text { Confidence } \\
\text { Interval for B }\end{array}$} & \multicolumn{2}{|c|}{$\begin{array}{l}\text { Collinearity } \\
\text { Statistics }\end{array}$} \\
\hline & & B & $\begin{array}{l}\text { Std. } \\
\text { Error }\end{array}$ & & $\begin{array}{l}\text { Lower } \\
\text { Bound }\end{array}$ & $\begin{array}{l}\text { Upper } \\
\text { Bound }\end{array}$ & Tolerance & VIF \\
\hline \multirow{4}{*}{1} & (Constant) & ,857 & 5,090 & & $-9,247$ & 10,960 & & \\
\hline & $\begin{array}{l}\text { KUALITAS } \\
\text { PRODUK }\end{array}$ & , 162 & , 080 &, 150 & ,003 & ,321 & 759, & 1,318 \\
\hline & SUKU BUNGA & ,514 & 083 & ,488 & ,348 & 679 & 663 & 1,508 \\
\hline & $\begin{array}{l}\text { ATRIBUT } \\
\text { PROPERTY }\end{array}$ & ,391 & ,093 & ,310 & ,206 &, 575 & ,769 & 1,301 \\
\hline
\end{tabular}

Sumber : Hasil Perhitungan SPSS, 2015

Tabel di atas memperlihatkan nilai VIF (Variance Inflation Factor) masing-masing variabel independent (variabel Kualitas Produk, variabel Suku Bunga dan variabel Atribut Property) adalah sebesar 1,318; 1,508; dan 1,301. Nilai-nilai tersebut lebih kecil dari 5. Nilai yang lebih kecil dari 5 membuktikan bahwa persamaan regresi linier berganda yang diperoleh mengalami problemmultikolinearitas.Jika terjadi multikolinearitas pada variabel-variabel independen, maka akan berakibat koefisien regresi linier berguna tidak dapat ditentukan, dan standar deviasi akan memiliki nilai tak terhingga, sehingga model regresi dapat digunakan.

\section{Uji Heterokedastisitas}

Berdasar hasil perhitungan data-data yang diolah secara statistik, dapat diperoleh gambaran sebagai berikut: 

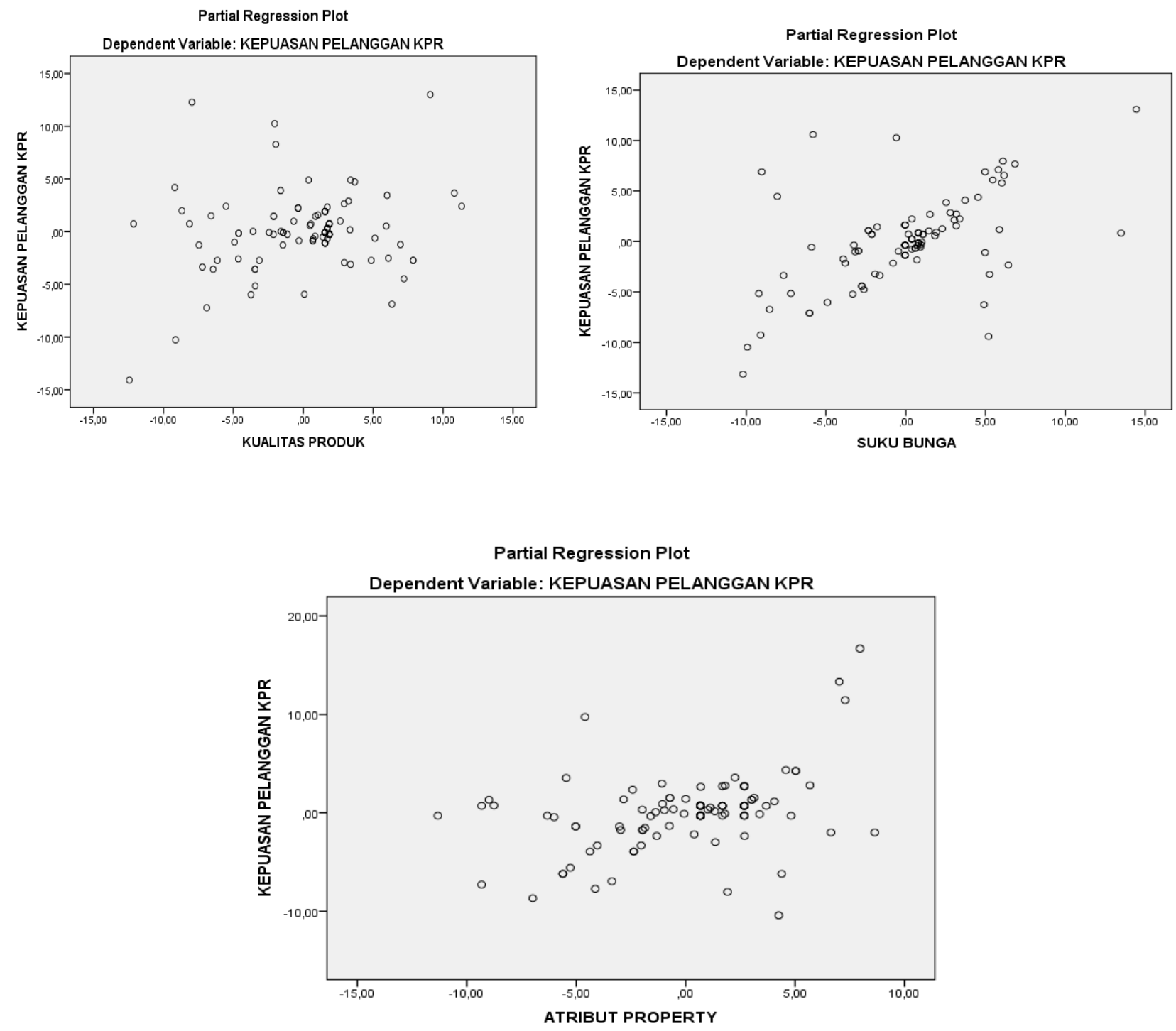

Dari gambar-gambar di atas memperlihatkan bahwa titik-titik (data) menyebar secara acak, tidak membentuk suatu pola tertentu yang jelas, serta tersebar baik di atas maupun di bawah angka 0 pada sumbu Y. Dengan demikian, terjadi heteroskedastisitas pada model regresi.

\section{KESIMPULAN DAN SARAN}

\subsection{Kesimpulan}

1. Secara parsial variabel kualitas produk memiliki pengaruh yang positif terhadap variabel kepuasan nasabah KPR di lingkungan MaybankIndonesia Tangerang. Besarnya nilai pengaruh variabel kualitas produk terhadap variabel kepuasan nasabahKPR adalah 0,162. Variabelkualitas produk inimemilikipengaruhyang terendah/terkecil terhadap variable kepuasannasabah KPR.

2. Secara parsial variabelsuku bunga memiliki pengaruh yang positif dan signifikanterhadap variabel kepuasan nasabahKPR di lingkungan Maybank Indonesia Tangerang. Besarnya nilai pengaruh variabelsuku bunga terhadap variabel kepuasan nasabahKPR adalah 
0,514.Variabelsukubungamerupakanvariabel yang paling dominandalammempengaruhi variable kepuasannasabah KPR.

3. Secara parsial variabelatribut property memiliki pengaruh yang positif terhadap variabelkepuasan nasabahKPR di lingkungan MaybankIndonesia Tangerang. Besarnya nilai pengaruh variabel atribut property pegawai terhadap variabel kepuasan nasabah KPR adalah 0,391.Variabelatribut property merupakanvariabel yang kedua dalammempengaruhi variable kepuasannasabahKPR .

4. Variabel-variabel kualitas produk,suku bunga danatribut property secara bersama-sama memiliki pengaruh yang positif dan signifikanterhadap variabel kepuasan nasabah KPR di lingkungan Maybank Indonesia Tangerang. Berdasar Nilai r Square ( $\mathrm{r}$ determinan) pengaruh ketiganya adalah sebesar 0,599, yang berartibahwaketiga variabel independen tersebut mempunyaipengaruhsebesar59,9\% terhadapvariabel kepuasan nasabah KPR.Sedangkan, sisanya $(40,1 \%)$ dipengaruhiolehfaktor-faktor lain.

\subsection{Saran-saran}

1. Pimpinan perlu memperhatikan secara terus-menerus meningkatkan kualitas produk yang dihasilkan oleh perusahaan, khususnya produk KPR. Dalam kaitan ini, untuk meningkatkan kualitas adalah memiliki spesifikasi yang sesuai dengan kebutuhan nasabah, sehingga menyebabkan nasabah merasa puas. Disisi lain, peningkatan kualitas produk adalah dengan memberikan pelayanan yang berkualitas (service quality) kepada nasabahnya.

2. Pimpinan perlu senantiasa memperhatikan suku bunga yang berlaku terkait dengan pemberian KPR. Dalam hal ini, pimpinan perlusenantiasa memperhatikan lingkungan strategis yang sangat dinamis dalam kerangka penentuan suku bunga KPR. Penentuan suku bunga KPR yang bersaing atau kompetitif dengan suku bunga KPR yang dikeluarkan oleh perbankan lain akan mendorong para nasabah untuk mengajukan KPR di Bank ini.

3. Pengembang perumahan perlu untuk meningkatkan atau memperkaya atribut property terhadap perumahan atau hunian yang ditawarkan kepada para nasabah. Dalam kaitan ini, pihak perbankan dan pihak pengembang perumahan perlu berkoordinasi untuk merumuskan cara-cara (strategi) untuk menarik nasabah terhadap produk KPR yang ditawarkan perbankan dan pengembang perumahan. Salah satu strategi yang dapat dilakukan adalah dengan memperkaya atau melengkapi perumahan atau komplek hunian dengan sarana prasarana yang mendukung dan memberi kenyamanan kehidupan masyarakat penghuninya.

4. Hasilpenelitianinimemperlihatkan bahwakepuasan nasabah KPR tidak hanya dipengaruhi oleh variabel yang diteliti (variabel kualitasproduk, variabel suku bunga dan variabel atribut property). Oleh karena itu, pimpinan perlu memperhatikan hal-hal lain yang dapat mempengaruhi peningkatankepuasan nasabahKPR di lingkungan Maybank Indonesia Tangerang, misalnya meningkatkan pelayanan perbankkan, menyederhanakan proses dan persyaratan bagi nasabah dalam mengajukan kredit KPR dan lain sebagainya. Disisi lain, secara akademis hasil penelitian ini dapat menjadi acuan atau referensi bagi kegiatan penelitianpenelitian berikutnya yang akan meneliti/membahas variabel-variabel tersebut. 


\section{DAFTAR PUSTAKA}

Dharmmesta, B.S. \& Handoko, H., Manajemen Pemasaran: Analisis Perilaku Konsumen, Yogyakarta: PBFE Universitas Gadjah Mada, 2012.

Dessler, Gary, Manajemen Sumber Daya Manusia (Edisi Bahasa Indonesia), (Jakarta: Prenhallindo, 2012.

Ferrel, O.C, Hirt, G. \& Ferrel, L., Business: A Changing World. New York: McGraw-Hill Book Company. 2012

Fraser, T.M., Stress dan Kepuasan Kerja, Acuan Mencari Alternatif Untuk Meningkatkan Kepuasan Kerja Karyawan Dalam Lingkungan Kerja Yang Sesuai, Jakarta:PT: Pustaka Binaman Pressindo, 2012.

Hampden, Charles, Human Resources Management, Irwin Publisher, Toronto, 2011.

Handoko, T. Hani, edisi 2, Manajemen Personalia dan Sumberdaya Manusia, BPFE, Yogyakarta, 2011.

Hugh dan Daniel, Organizational Behavior, Human Behavior at Work, Auckland, 2010.

Irawan, Prasetya, Analisis Kinerja, Jakarta: tanpa penerbit, 2013.

-----, Logika dan Prosedur Penelitian, Pengantar Teori dan Panduan Praktis Penelitian Sosial Bagi Mahasiswa dan Peneliti Pemula, Cetakan Pertama, Jakarta : STIA LAN RI Pres, 2012.

J. Scherriton \& J.L. Stren, Foundations of Behavioral Research, New York : Holt Rinehart \& Winston, 2012.

Kotler, John P, Leading Change, Menjadi Pionir Perubahan, Jakarta: PT. Gramedia, 2011.

Kotler, P., Marketing Management: Analysis, Planning, and Control. 4th Ed. London: PrenticeHall, Inc, 2012.

Kotter J.P. and Heskett S.L., Corporate Culture and Performance (alih bahasa Benyamin Molan), Jakarta: PT.Prenhalindo Simon \& Schuster (Asia) Pte Ltd, 2012.

Kreitner and Angele Knicki, Organizational Behavior (alih bahasa Erly Suwandy), Jakarta: Salemba Empat, 2013.

Pascale, Personnel : The Management of Human Resources, Allyn and Bacon Inc., Boston, 2012.

Nitissemito, Alex S., Manajemen Personalia, Jakarta: Ghalia Indonesia, 2010.

Ndraha, Taliziduhu, Teori Manajemen Sumber Daya Manusia, Jilid I, Jakarta: Institut Ilmu Pemerintahan, 2012.

Ranupandojo, Heidjrahman dan Suad Husnan, edisi 2, Manajemen Personalia, BPFE, Yogyakarta, 2010.

Robbins, Stephen, Perilaku Organisasi: Konsep-Kontroversi-Aplikasi, Jilid 2, Prentice Hall, Inc. A. Simon aned Schuster Company, New Jersey, 2010.

Siagian, P. Sondang, Manajemen Sumber Daya Manusia, Cetakan Kelima, Jakarta : Bumi Aksara, 2010.

, Manajemen Sumber Daya Manusia, Cetakan Kesepuluh, Jakarta : Bumi Aksara, 2011.

Soekemi, R.B., Jakoeb Hidajat dan Koesjono, Hubungan Ketenagakerjaan, Karunika dan Universitas Terbuka, Jakarta, 2010. 
Stanton, W.J., Fundamentals of Marketing, 5th Ed. Tokyo: Kogakusha, McGraw-Hill Book Company, 2013.

Sugiyono, Metode Penelitian Administrasi, Alfabeta, Bandung, 2011.

Sugiyono, Metode Penelitian Sosial, Alfabeta, Bandung, 2011.

Triguno, Budaya Kerja, PT. Golden Trayon Press, Jakarta, 2012.

Warren G, Bennis, et.al, The Planning of Change, New York: CBS College Publishing, 2011. 